\title{
PENGARUH PEMBERIAN TAKARAN FUNGI MIKORIZA ARBUSKULAR (FMA) TERHADAP PERTUMBUHAN BIBIT KOPI ARABIKA (Coffea arabica L.)
}

\section{EFFECT OF ARBUSCULAR MYCORRHIZAL FUNGI (AMF) DOSAGE ON GROWTH OF ARABICA COFFEE (Coffea arabica L.) SEEDLING}

\author{
Lia Sugiarti dan Yana Taryana \\ Fakultas Pertanian Universitas Winaya Mukti \\ Korespondensi : liasugiarti82@gmail.com \\ Diterima 27 November 2017 / Disetujui 1 Juli 2018
}

\begin{abstract}
ABSTRAK
Fungi Mikoriza Arbuskular (FMA) banyak ditemukan pada perakaran kopi. Tujuan dari percobaan ini untuk mempelajari pengaruh pemberian takaran FMA terhadap pertumbuhan bibit kopi Arabika (Coffea arabica L). Percobaan dilaksanakan dari bulan Mei sampai dengan bulan Agustus 2017, bertempat di Kebun Percobaan Fakultas Pertanian Universitas Winaya Mukti, Tanjungsari, Sumedang, dengan ketinggian tempat $850 \mathrm{~m}$ dpl. Rancangan yang digunakan dalam penelitian ini adalah Rancangan Acak Kelompok (RAK) terdiri atas enam perlakuan dan diulang sebanyak empat kali. Perlakuan takaran FMA jenis Glomus agregatum yang terdiri dari $\mathrm{A}=0 \mathrm{~g} \tan ^{-1} ; \mathrm{B}=10 \mathrm{~g} \mathrm{tan}^{-1} ; \mathrm{C}=20 \mathrm{~g} \mathrm{tan}^{-1} ; \mathrm{D}=30 \mathrm{~g} \mathrm{tan}^{-1} ; \mathrm{E}=40 \mathrm{~g} \tan ;$ dan $\mathrm{F}=$ $50 \mathrm{~g} \mathrm{tan}^{-1}$. Hasil percobaan menunjukkan bahwa pemberian takaran inokulasi FMA berpengaruh terhadap tinggi tanaman dan bobot kering tanaman. Pemberian takaran inokulasi FMA dengan takaran $40 \mathrm{~g} \mathrm{tan}^{-1}$ - sampai $50 \mathrm{~g} \mathrm{tan}^{-1}$ memberikan pengaruh yang terbaik terhadap tinggi tanaman dan bobot kering tanaman. Dengan demikian pemberian FMA $40 \mathrm{~g} \mathrm{tan}^{-1}-$ sampai $50 \mathrm{~g} \mathrm{tan}^{-1}$ dapat digunakan pada pembibitan kopi arabika.
\end{abstract}

Kata Kunci : Arabika, Bibit, FMA, Kopi, Takaran

\begin{abstract}
Arbuscular Mycorrhizal Fungi (AMF) is commonly found in coffee roots. The purpose of the research was to study effect of AMF application on growth of arabica coffee seedling (Coffea arabica L). The research was conducted from May to August 2017, at Research Station of Agriculture Faculty Universitas Winaya Mukti, Tanjungsari Sumedang, at $850 \mathrm{~m}$ above sea levels. The research used Randomized Block Design (RBD) consisted of six treatments and four replications. The treatment was dosage of $A M F$ from Glomus agregatum type i.e. : $A=0 \mathrm{~g}$ plant $^{-1} ; \mathrm{B}=10 \mathrm{~g} \mathrm{plant}^{-1} ; \mathrm{C}=20 \mathrm{~g} \mathrm{plant}^{-1} ; \mathrm{D}=30 \mathrm{~g} \mathrm{plant}^{-1} ; \mathrm{E}=40 \mathrm{~g} \mathrm{plant}^{-1} ; \mathrm{F}=50 \mathrm{~g} \mathrm{plant}^{-1}$. Each plot consisted of 10 polybag with 4 sample plants. The research result showed that application of AMF affected on plant height and dry weight of plant, which the best effect was generated by $40 \mathrm{~g}_{\text {plant }}{ }^{-1}$ - until $50 \mathrm{~g}_{\text {plant }}{ }^{-1}$ dosages. It is simply that AMF $40 \mathrm{~g} \mathrm{plant}^{-1}-50 \mathrm{~g} \mathrm{plant}^{-1}$ can be used in arabica coffee nursery.
\end{abstract}

Keywords : AMF, Arabica, Coffee, Dosage, Seedling

ISSN : 2407-7933

Cyte this as: Sugiarti, L \& Taryana, Y. (2018). Pengaruh pemberian takaran fungi mikoriza arbuskular (FMA) terhadap pertumbuhan bibit kopi Arabika (Coffea arabica L.). Jurnal Agro, 5(1), 61-65. https://doi.org/10.15575/1813 


\section{PENDAHULUAN}

Tanaman kopi merupakan salah satu sumber penghasil devisa negara Indonesia. Luas areal perkebunan kopi mengalami peningkatan dalam kurun waktu 20 tahun terakhir (Direktorat Jenderal Perkebunan, Kementerian Pertanian, 2013), akan tetapi produktivitas dan mutu hasil dari pengolahan kopi di Indonesia belum maksimal seperti yang diharapkan. Terdapat tiga jenis kopi yang dapat tumbuh baik di Indonesia, namun yang banyak dibudidayakan adalah kopi jenis Robusta dan Arabika, sebab kedua jenis kopi tersebut yang bernilai ekonomis tinggi (Pusat Data dan Sistem Informasi Pertanian Sekretariat Jendral-Kementrian Pertanian, 2016).

Perkebunan kopi di Indonesia masih didominasi oleh perkebunan rakyat dengan bahan baku dan pemeliharaan tergolong rendah. Untuk masalah pemeliharaan, petani sering meminimalisir penggunaan pupuk, padahal untuk tanaman perkebunan kopi pemupukan adalah modal yang paling utama. Terlebih apabila tanaman kopi yang ditanam pada Andisol. Jenis tanah ini memiliki retensi fosfat yang tinggi (lebih dari 85\%) sehingga ketersediaan fosfat bagi tanaman cukup rendah (Sagala et al., 2013). Upaya untuk meningkatkan ketersediaan $\mathrm{P}$ pada tanah Andisol dapat dilakukan dengan pemberian amelioran (seperti pupuk kandang, jerami padi dan gamal) dan mikoriza (Karnilawati et al., 2013).

Mikoriza merupakan satu asosiasi simbiotik terpenting antar mikroba, kehadiran fungi rhizosfir dan akar tanaman (Delian et al., 2011). Fungi memiliki miselium yang dapat memperluas kontak area tanah dengan akar tanaman, sehingga kehadiran dalam asosiasi tersebut mampu meningkatkan serapan hara dan air (Fokom et al., 2012). FMA secara alami banyak ditemukan pada perakaran tanaman kopi (Muleta et al., 2007), sehingga Rini et al. (2014) menyimpulkan adanya simbiosis antara FMA dengan tanaman kopi. Pada rhizosfir tanaman kopi arabika, Dewi (2016) menemukan spora Acaulospora dan Glomus, sedangkan pada kopi robusta diperoleh Acaulospora, Gigaspora, dan Glomus. Dalam penelitian ini digunakan Glomus karena Jenis FMA ini paling banyak ditemukan pada berbagai tanah, mulai dari tanah gambut (Pangaribuan, 2014) sampai Andisol di dataran tinggi (Nurbaity et al, 2010). Selain jenis, faktor lain yang menentukan keberhasilan FMA adalah takarannya. Ramadhan et al (2015) menemukan aplikasi konsorsium inokulum FMA $5 \mathrm{~g} \mathrm{tan}^{-1}$ belum berhasil meningkatkan pertumbuhan dan hasil tanaman, sementara Hidayat et al (2017) menyimpulkan aplikasi FMA 5-15 $\mathrm{g} \mathrm{tan}^{-1}$ memberikan pengaruh sama terhadap bobot jagung berkelobot, sehingga perlu diteliti peningkatan takaran aplikasi FMA. Tujuan dari penelitian ini adalah untuk mengetahui pengaruh takaran FMA terhadap pertumbuhan bibit kopi Arabika.

\section{BAHAN DAN METODE}

Penelitian dilaksanakan dari bulan Mei sampai dengan bulan Agustus 2017, bertempat di Kebun Percobaan Fakultas Pertanian Universitas Winaya Mukti, Tanjungsari, Sumedang, dengan ketinggian tempat $850 \mathrm{~m}$ dpl. Bahan dan alat yang digunakan dalam penelitian ini adalah bibit semai tanaman kopi arabika stadia kepelan berumur 1,5 bulan, FMA jenis Glomus 
agregatum, tanah, pupuk kandang domba, polybag ukuran $20 \mathrm{~cm} \times 30 \mathrm{~cm}$, mistar, timbangan elektrik dan oven pengering.

Rancangan yang digunakan dalam penelitian ini adalah Rancangan Acak Kelompok (RAK) terdiri atas enam perlakuan dan diulang sebanyak empat kali. Perlakuan takaran FMA terdiri dari $\mathrm{A}=$ $0 \mathrm{~g} \tan ^{-1} ; \mathrm{B}=10 \mathrm{~g} \mathrm{tan}^{-1} ; \mathrm{C}=20 \mathrm{~g} \mathrm{tan}^{-1} ; \mathrm{D}=$ $30 \mathrm{~g} \mathrm{tan}^{-1} ; \mathrm{E}=40 \mathrm{~g}_{\tan ^{-1}}$; dan $\mathrm{F}=50 \mathrm{~g} \mathrm{tan}^{-1}$. Setiap plot terdiri dari 10 polibag dengan tanaman contoh sebanyak 4 tanaman. Pengamatan dilakukan pada umur 4 bulan setelah tanam (BST) terhadap beberapa parameter pertumbuhan seperti tinggi tanaman, jumlah daun per tanaman, panjang akar, bobot kering akar dan bobot kering tanaman. Data yang diperoleh diolah dengan analisis ragam dan dilanjutkan dengan uji jarak berganda Duncan pada taraf nyata $5 \%$.

\section{HASIL DAN PEMBAHASAN}

Pemberian takaran inokulan FMA yang berbeda memberikan pengaruh yang berbeda tidak nyata terhadap jumlah daun dan panjang akar, tetapi memberikan pengaruh yang nyata terhadap tinggi tanaman (Tabel 1). Untuk variabel tinggi tanaman, semakin tinggi takaran inokulan FMA maka pertumbuhan tinggi bibit kopi pun semakin baik, sesuai penelitian Andrade et al. (2009) bahwa perlakuan mikoriza memberikan pengaruh terhadap tinggi tanaman kopi mulai terlihat ketika tanaman berumur 4 sampai 6 BST. Hal ini diduga bahwa dengan pemberian inokulan FMA mampu membantu penyerapan nutrisi dan unsur hara oleh akar kopi dibandingkan tanpa FMA. FMA dapat meningkatkan pengambilan hara melalui difusi hara dari dalam tanah ke akar karena bidang penyerapan oleh hifa FMA yang lebih luas (Fokoma et al., 2012), sehingga pertumbuhan tanaman yang diinokulasi FMA akan lebih baik daripada tanaman yang tidak diinokulasi FMA.

Tabel 1. Pengaruh FMA terhadap tinggi tanaman, jumlah daun dan panjang akar bibit kopi arabika umur 4 BST

\begin{tabular}{cccc}
\hline Takaran FMA & $\begin{array}{c}\text { Tinggi } \\
\text { tanaman } \\
\text { (cm) }\end{array}$ & $\begin{array}{c}\text { Jumlah } \\
\text { daun } \\
\text { (helai) }\end{array}$ & $\begin{array}{c}\text { Panjang } \\
\text { akar } \\
\text { (cm) }\end{array}$ \\
\hline $\mathrm{A}\left(0 \mathrm{~g} \mathrm{tan}^{-1}\right)$ & $7,36 \mathrm{a}$ & $7,69 \mathrm{a}$ & $8,65 \mathrm{a}$ \\
$\mathrm{B}\left(10 \mathrm{~g} \mathrm{tan}^{-1}\right)$ & $10,05 \mathrm{ab}$ & $8,20 \mathrm{a}$ & $8,06 \mathrm{a}$ \\
$\mathrm{C}\left(20 \mathrm{~g} \mathrm{tan}^{-1}\right)$ & $9,14 \mathrm{ab}$ & $8,19 \mathrm{a}$ & $8,43 \mathrm{a}$ \\
$\mathrm{D}\left(30 \mathrm{~g} \mathrm{tan}^{-1}\right)$ & $10,12 \mathrm{~b}$ & $8,50 \mathrm{a}$ & $8,53 \mathrm{a}$ \\
$\mathrm{E}\left(40 \mathrm{~g} \mathrm{tan}^{-1}\right)$ & $12,71 \mathrm{c}$ & $8,31 \mathrm{a}$ & $9,20 \mathrm{a}$ \\
$\mathrm{F}\left(50 \mathrm{~g} \mathrm{tan}^{-1}\right)$ & $12,50 \mathrm{c}$ & $8,61 \mathrm{a}$ & $9,24 \mathrm{a}$ \\
\hline Keterangan : Angka rata-rata yang diikuti huruf yang \\
\multicolumn{4}{c}{ sama menunjukkan berbeda tidak } \\
nyata berdasarkan Uji Jarak Berganda \\
\multicolumn{4}{c}{ Duncan pada taraf nyata 5\%. }
\end{tabular}

Pemberian inokulan FMA tidak memberikan pengaruh yang nyata terhadap jumlah daun dan panjang akar. Hal ini kemungkinan disebabkan karena pemberian inokulan FMA pada tanaman kopi memerlukan waktu inokulasi lebih lama sehingga dalam jangka waktu 4 bulan belum terlihat peningkatan pertambahan jumlah daunnya.

Pemberian takaran inokulan FMA tidak menunjukkan hasil yang nyata terhadap panjang akar. Hal ini diduga karena media tanam yang terlalu kecil dan tempat yang terbatas, sehingga berpengaruh terhadap laju perkembangan akar. Hasil akan sangat berbeda dengan perakaran tanaman yang menggunakan media langsung di lapangan (Badal, 2009).

Pada Tabel 2, pemberian inokulan FMA berpengaruh tidak nyata terhadap bobot 
kering akar, tetapi berpengaruh nyata terhadap bobot kering tanaman benih kopi umur 4 BST. Hasil penelitian ini sejalan dengan Janoušková et al. (2013) yang mendapatkan peningkatan bio masa pupus tanaman dengan adanya pemberian FMA. Verbruggen et al. (2013) melaporkan bahwa inokulasi mikoriza meningkatkan bobot biomassa tanaman sebesar $23 \%$. Peningkatan berat kering tanaman ditunjang pula oleh meningkatnya tinggi tanaman, jumlah daun, diameter batang dan jumlah akar. Salgado et al. (2017) melaporkan pemberian FMA dapat berasosiasi dengan tanaman jagung. $\mathrm{Hal}$ ini diakibatkan hifa-hifa eksternal jamur FMA dapat membantu penyerapan air maupun unsur-unsur hara yang digunakan dalam proses metabolisme di dalam tubuh tanaman sehingga dapat memacu pertumbuhan dan perkembangan organorgan reproduktif.

Tabel 2. Pengaruh FMA terhadap bobot kering akar dan bobot kering tanaman bibit kopi arabika umur 4 BST

\begin{tabular}{ccc}
$\begin{array}{c}\text { Takaran } \\
\text { FMA }\end{array}$ & $\begin{array}{c}\text { Bobot kering } \\
\text { akar (g) }\end{array}$ & $\begin{array}{c}\text { Bobot } \\
\text { kering } \\
\text { tanaman (g) }\end{array}$ \\
\hline $\mathrm{A}\left(0 \mathrm{~g} \mathrm{tan}^{-1}\right)$ & $0,18 \mathrm{a}$ & $0,44 \mathrm{a}$ \\
$\mathrm{B}\left(10 \mathrm{~g} \mathrm{tan}^{-1}\right)$ & $0,21 \mathrm{a}$ & $0,46 \mathrm{ab}$ \\
$\mathrm{C}\left(20 \mathrm{~g} \mathrm{tan}^{-1}\right)$ & $0,18 \mathrm{a}$ & $0,49 \mathrm{~b}$ \\
$\mathrm{D}\left(30 \mathrm{~g} \mathrm{tan}^{-1}\right)$ & $0,21 \mathrm{a}$ & $0,49 \mathrm{~b}$ \\
$\mathrm{E}\left(40 \mathrm{~g} \mathrm{tan}^{-1}\right)$ & $0,22 \mathrm{a}$ & $0,58 \mathrm{c}$ \\
$\mathrm{F}\left(50 \mathrm{~g} \mathrm{tan}^{-1}\right)$ & $0,23 \mathrm{a}$ & $0,59 \mathrm{c}$ \\
\hline Keterangan : Angka rata-rata yang diikuti huruf yang \\
\multicolumn{3}{c}{ sama menunjukkan berbeda tidak } \\
nyata berdasarkan Uji Jarak Berganda \\
\multicolumn{3}{c}{ Duncan pada taraf nyata 5\%. }
\end{tabular}

Pemberian inokulan FMA dengan takaran $40 \mathrm{~g}$ per tanaman sampai $50 \mathrm{~g}$ per tanaman memberikan pengaruh yang terbaik terhadap tinggi tanaman dan bobot kering tanaman. Hal ini sesuai dengan pernyataan Li et al. (2015) bahwa pemberian FMA meningkatkan aktifitas asam fosfatase dan kandungan fosfor tersedia di rhizosfir, melalui cara melepaskan ikatan $\mathrm{P}$ yang terikat di dalam tanah menjadi terlarut dan tersedia bagi tanaman. Prinsip kerja dari FMA adalah menginfeksi sistem perakaran tanaman inang, memproduksi jalinan hifa secara intensif sehingga tanaman yang mengandung FMA akan mampu meningkatkan kapasitas dalam penyerapan unsur hara (Dewi et al., 2016). Tanaman yang bermikoriza akan tumbuh lebih baik daripada tanaman tanpa mikoriza, sebab mikoriza secara efektif dapat meningkatkan penyerapan unsur hara baik unsur hara makro maupun mikro.

\section{SIMPULAN}

Berdasarkan hasil percobaan dan pembahasan dapat ditarik kesimpulan sebagai berikut :

1. Pemberian takaran inokulasi FMA berpengaruh terhadap tinggi tanaman dan bobot kering tanaman bibit Kopi Arabika umur 4 BST.

2. Pemberian takaran inokulasi FMA dengan takaran $40 \mathrm{~g} \mathrm{tan}^{-1}$ sampai $50 \mathrm{~g}$ $\tan ^{-1}$ memberikan pengaruh yang paling baik terhadap tinggi tanaman dan bobot kering tanaman.

3. FMA dengan takaran $40 \mathrm{~g} \mathrm{tan}^{-1}$ sampai $50 \mathrm{~g} \tan ^{-1}$ dapat diaplikasikan pada pembibitan kopi arabika.

\section{DAFTAR PUSTAKA}

Andrade, S. A. L., Mazzafera, P., Schiavinato, M. A., \& Silveira, A. P. D. 
(2009). Arbuscularmycorrhizal association in coffee. Journal of Agricultural Science, 147(2), 105-115. https://doi.org/10.1017/\$00218596080 08344

Badal, B. (2009). Pemanfaatan Cendawan Mikoriza Vesikular Arbuskular (CMA) dalam pembibitan tanaman kopi (Coffea robusta L.) pada Ultisol. Jur. Embrio, 2 (1), 26-31. Retrieved from journal.unitas-

pdg.ac.id/downlotfile.php?file=No.\%20 4\%20Bustari\%20Badal.doc

Delian, E., Chira, A., Chira, L., \& Săvulescu, E. (2011). Arbuscular mycorrhizae: an Overview. South Western Journal of Horticulture, Biology and Environment, 2(2), 167-192. Retrieved from biozoojournals.ro/swjhbe/v2n2/06.swjh be.v2n2.Delian.pdf

Dewi, P. A. M. Y., Sritamin, M, \& Suada, I. K. Identifikasi mikoriza vesikular arbuskular pada rhizosfer kopi arabika (Coffea arabica L.) dan kopi robusta (Coffea robusta L.) dan perbanyakannya dengan media zeolit. E-Jurnal Agroekoteknologi Tropika (Journal of Tropical Agroecotechnology), 5(2), 181190. Retrieved from erepo.unud.ac.id/10864/1/44b6c28d39 f9226cc0622c7c49d9f528.pdf

Direktorat Jenderal Perkebunan, Kementerian Pertanian. (2013). Pedoman Teknis Pengembangan Tanaman Kopi 2014. Retrieved from http://ditjenbun.pertanian.go.id/downl ot.php?file=Pedoman\%20Teknis\%20Pen gembangan\%20Tanaman\%20Kopi.pdf

Fokom, R., Adamou, S., Teugwa, M.C., Boyogueno, A.D.B ... \& Zollo, P. H. A. (2012). Glomalin related soil protein, carbon, nitrogen and soil aggregate stability as affected by land use variation in the humid forest zone of south Cameroon. Soil Tillage Res, 120, 69-75.

Hidayat, C., Rosdiana, R., Frasetya, B., \&
Hasani, S. (2017). Improvement of physical properties of inceptisols and yield of sweet corn affected by arbuscular mycorrhizal fungi and manure applications. 2nd International Conference on Sustainable Agriculture and Food Security: A Comprehensive Approach, KnE Life Sciences, pages 158163. DOI 10.18502/kls.v2i6.1033

Janoušková, M., Krak, K., Wagg, C., Štorchová, H., Caklová, P., \& Vosátka, M. (2013). Effects of inoculum additions in the presence of a preestablished arbuscular mycorrhizal fungal community. Applied and Environmental Microbiology, 79(20), 6507-6515. http://dx.doi.org/10.1128/AEM.0213513

Karnilawati, Sufardi \& Syakur. (2013). Phosfat Tersedia, serapannya serta pertumbuhan jagung (Zea mays) akibat amelioran dan mikoriza pada andisol. Jurnal Manajemen Sumber Daya Lahan, 2(3), 231-239.

Li, S., Bi, Y. L, Kong, W., Yu, H., Lang, Q., \& Miao, Y. (2015). Effects of arbuscular mycorrhizal fungi on ecological restoration in coal mining areas. Russian Journal of Ecology, 46(5), 431-437. https://doi.org/10.1134/S10674136150 50173

Muleta, D., Assefa, F., Nemomissa, S., \& Granhall, U. (2007). Composition of coffee shade tree species and density of indigenous arbuscular mycorrhizal fungi (AMF) spores in Bonga natural coffee forest, southwestern Ethiopia. Forest Ecology and Management, 241(1-3), 145-154.

https://doi.org/10.1016/J.FORECO.2007 .01 .021

Nurbaity, A., Sunarto, T., Hindersah, R., Solihin, A., Kalay, M. (2010). Spatial variability of arbuscular mycorrhizal fungi and potato cyst nematodes isolated from agricultural area at Pangalengan district West Java 
Indonesia. Proceeding of International Seminar on Biotechnology for Enhancement of Tropical Biodiversity, October 2010, 225-231.

Pangaribuan, N. Penjaringan cendawan mikoriza arbuskula indigenous dari lahan penanaman jagung dan kacang kedelai pada gambut Kalimantan Barat Jurnal Agro, 1(1), 50-60. https://doi.org/10.15575/81

Pusat Data dan Sistem Informasi Pertanian Sekretariat Jendral-Kementrian Pertanian. (2016). Outlook Kopi. Komoditas Pertanian Subsektor Perkebunan, 1-25.

Ramadhan, M. F., Hidayat, C., \& Hasani, S. (2015). Pengaruh aplikasi ragam bahan organik dan FMA terhadap pertumbuhan dan hasil tanaman cabai (Capsicum annum L.) varietas Landung padxa tanah pasca galian C. J. Agro, 2(2). https://doi.org/10.15575/438

Rini, M. V, Januarsyah, A. D., \& Sugiatno. (2014). Pengaruh lima jenis fungi mikoriza arbuskular dan dosis pupuk anorganik pada pertumbuhan bibit kopi Robusta (Coffea canephora Pierre). In Prosiding Seminar Nasional Pengembangan Teknologi Pertanian Politeknik Negeri Lampung 24 Mei 2014.
Retrieved from jurnal.polinela.ac.id/index.php/PROSIDI NG/article/viewFile/437/304

Sagala, Y., Hanafiah, A. S., \& Razali. (2013). Peranan mikoriza terhadap pertumbuhan, serapan $\mathrm{P}$ dan $\mathrm{Cd}$ tanaman sawi (Brassica juncea L.) serta kadar $\mathrm{P}$ dan $\mathrm{Cd}$ Andisol yang diberi pupuk fosfat alam. Jurnal Online Agroekoteknologi, 2(1), 487-500. Retrieved from https://jurnal.usu.ac.id/index.php/agro ekoteknologi/article/view/5866/2589

Salgado, F. H. M., Moreira, F. M. de S., Siqueira, J. O., Barbosa, R. H., Paulino, H. B., \& Carneiro, M. A. C. (2017). Arbuscular mycorrhizal fungi and colonization stimulant in cotton and maize. Ciência Rural, 47(6), 1-8. https://doi.org/10.1590/01038478 cr20151535

Verbruggen, E., van der Heijden, M. G. A., Rilig, M. C., \& Kiers, E. T. (2013). Mycorrhizal fungal establishment in agricultural soils: factors determining inoculation success. New Phytologist, 197, 1104-1109. https://doi.org/10.1111/j.14698137.2012.04348.x 